\title{
MORE IN COMMON (LAW) THAN ORIGINALLY THOUGHT? A THEORETICAL FIRST COMPARISON OF THE MAGNA CARTA AND THE KSIĘGA ELBLĄSKA
}

\begin{abstract}
Medieval legal scholars generally do not compare the Polish and English legal systems, though in the $13^{\text {th }}$ century they share a surprising number of similarities. This is especially clear if one considers the convergent of evolution of legal institutions in response to socio-historical problems. This is concretely traced through historical and textual analysis of Magna Carta and Księga Elblaska, two foundational texts in their respective legal systems. Ramifications of this new comparative perspective are discussed, with avenues of further research outlined.
\end{abstract}

Keywords: Magna Carta; Księga Elblaska; Comparative Legal History; Convergent Legal Evolution.

\section{INTRODUCTION}

In the comparative history of European legal systems, Poland and England are nearly never put together in the same sentence. One is an unremarkable member of the civil law family, the other the author of the common law, yet the similarities are deeper than they appear at first: the adoption of civil law was more the choice of the imperial powers that divided Poland, than her natural development, which retains legal developments closer to English law than to the rest of the continent. Indeed, both share a stubborn persistence of customary legal traditions down to the modern era, despite the varied efforts of kings and conquerors (Gałędek, Klimaszewska 2018; Matuszewski 2015; Karabowicz 2014; Milsom 1969, 1; Lobingier 1946, 960; Blackstone 1893a, 34; Blackstone 1893b, 535-536). Stated simply, the classification of Polish law as civil is both anachronistic and over-simplistic.

How is the Polish legal system to be interpreted, then? Comparing works across cultures is always a tricky business, but a combination of certain historiographical and jurisprudential foundations will not only make this possible, if in an introductory manner, but also outline a future program of comparative legal research, beginning with the foundational works of their respective systems

* University of Łódź, Faculty of Law and Administration, Department of Political and Legal Doctrines, pat.higgins@gmail.com. Unless otherwise indicated, all translations are my own. 
in the $13^{\text {th }}$ century - Magna Carta (MC) and Księga Elblaska (KE). Here, the interpretative key is a political and legal understanding of legal development, rather than a more compact, contextualist understanding. While this approach forfeits some exactness from historical circumstances, it gains broader comparability due to shared human nature and experience. Accordingly, the argument is presented as a provocation to, as well as anticipation of, future legal research.

\section{THREE JURISPRUDENTIAL AND HISTORIOGRAPHICAL FOUNDATIONS}

The three foundations are as follows:

1. An essentialist (praxeological) understanding of human nature.

If human beings everywhere in the world are more or less the same, there are only a limited number of human responses to a limited number of social situations, allowing for comparison of meaning, ideas, behaviours, institutions, etc. across societies and cultures.

2. Law is a solution or "coordinating devise" to socio-political problems.

"Law is not simply another way of reaching an economic or political result, although law may accomplish both these ends. We recognize the presence or absence of law in a society by its structure, not simply by its results [...] [W] e present an account of law as an institution characterized by the two features noted above: a system of distinctive reasoning and processes that is grounded in economic and political functionality" (Hadfield, Weingast 2011, 3).

Thus, law is both a set of general rules as well as processes. They are given meaning by, and are also a reflection of, their specific historical context. This sociological understanding of law is particularly relevant to common law:

The materials of the common law, therefore, were the custom of true communities whose geographical boundaries had in some cases divided peoples and cultures, and not just areas of governmental authority. But within each body of custom, what we think of as the law was not marked off from other aspects of society (Milsom 1969, 2).

3. The analogy of a convergent model of socio-historical evolution, rather than common descent.

Two prevailing theories of evolutionary change are common descent and convergent evolution (Glor 2010; Fried 1999; Griffiths 1996, 521). Though not mutually exclusive, they emphasise e origin or environment, respectively. Common descent explains how a trait is preserved, for example, only birds have feathers, therefore all birds came from a common ancestor that had feathers. Convergent evolution, on the other hand, explains how different animals evolved the same traits independently, due to similar environments. Most cave fish are not blind due to shared, blind ancestor, but rather that all underwater caves share a common factor - darkness. 
This analogy of evolutionary convergence has been used in legal theory before (Saks, Neufeld 2012, 121; Saks, Neufeld 2011, 144; Hostetler 2000, 598, 632), if somewhat reluctantly (Ruhl 1996, 1435). Most comparative legal history, at least in the medieval period, follows the common descendent model, emphasizing legal attributes. Instead, a convergent theory asks: were there similarities in the socio-political situation in England and Poland, and did these lead to similar legal solutions?

Synthesizing these three foundations induces: if people everywhere are more or less the same, with a limited combination of both social problems and solutions, then the $M C$ cannot be a completely isolated occurrence: there must be other documents that emerged under similar, comparable circumstances. Thus, the argument is not whether Poland was $a$ common law system, but whether it was common law-like. As it involves more criteria and dimensions for comparison, adopting a convergence model is less precise, and may only ask how similar the Polish legal system was to the common law, with it being ultimately impossible to definitely answer if Poland's law is or is not the common law Accordingly, the $M C$ and $K E$ are selected for comparison both given their similar pre-eminence in their own respective legal systems, as well as the character of legal solutions in both texts.

\section{3. $M C$ AND $K E$ AS HISTORICAL, RATHER THAN CONSTITUTIONAL TEXTS}

One of the foremost difficulties in common law scholarship is how to interpret $M C$, whose meaning and function have varied through time: scholars have defined it as a charter, a treaty, a constitution, etc., and caution that giving it a purely constitutional interpretation is anachronistic (Turner 2003, 106-108). ${ }^{1}$ Historians further note that $13^{\text {th }}$ century laws were generally concerned with procedural or practical manners, rather than constitutional or parliamentary concerns (Turner 2003, 121-122, 139; Arnold 1977, 330). The social situation in England since the fall of Rome had become quite complex, with a mix of peoples, cultures, and legal systems. Kings tended to be weak and laws were generally enacted on local, customary levels, until they were partially synthesized by Edward the Confessor, the second to last Anglo-Saxon king of England, often considered as a father of the common law (Brunner 1908, 20).

After Edward's death in 1066, followed by a protracted struggle, William the Conqueror won the throne of England for himself, but promised to more or less uphold the laws of Edward. Further, William and his Norman descendants

1 "The medieval mind cannot be measured in terms of modern conceptions [...] English lawyers were not in the forefront of philosophical thinkers of the day, because naturally they were occupied with more practical problems" (Potter 1948, 29). 
continued to follow their own laws, expressing little interest in legislating their new empire or changing the laws of those they conquered (Pollock and Maitland 2010, 67, 72; Plucknett 2010, 318; Baker 1990, 13; Brunner 1908, 21; Maitland 1908, 51, 54-55), and preferred to keep local law intact whenever possible (Milsom 1969, 9; McKechnie 1914, 79). By the time the dynasty passed to the Angevins and the Plantagenets, the Anglo-Saxon and Norman legal institutions fused, with legal historians assigning different weights to the Norman or Anglo-Saxon components (Plucknett 2010; Pollock, Maitland 2010; Baker 1990; Milsom 1968, 1-2, 7-8; Potter 1948; McKechnie 1914, 8), eventually producing the common law. ${ }^{2}$

Common law is thus generally understood in one of three senses: that it is a remnant of the Anglo-Saxon "ancient-constitution" that survived the Norman invasion of England (Blackstone 1893a, passim; Blackstone 1893b, passim, especially 532-552; Coke 2003) ${ }^{3}$; that it is a primarily administrative approach the Normans, Angevins, and Plantagenets invented where matters of justice and finances were centralized, such as the establishment of the Exchequer (McKechnie 1914, 12, 19); or the obvious, if unequal, synthesis of the two: Norman laws superimposed on an Anglo-Saxon super-structure (Turner 2003, 9). If there was any constitutional value to the laws established by the Normans, it was more restorative of pre-Norman Anglo-Saxon laws, as was the original understanding of Magna Carta (Pollock, Maitland 2010, 117; Coke 2003, 767-773; Turner 2003, 52, 93-95).

Over the centuries, the Norman barons increasingly mixed with the AngloSaxons and began to see themselves as English. By the turn of the $13^{\text {th }}$ century, wars on the Continent to keep control of France became increasingly unpopular and expensive. King John, an unpopular king before he disastrously lost his lands in France, found himself on the losing end of social change. ${ }^{4}$ An alliance of barons and the church under Stephen Langdon, Archbishop of Canterbury,

${ }^{2}$ The ancient collection of unwritten maxims and customs, which is called the common law, however compounded or from whatever fountains derived, had subsisted immemorially in this kingdom; and, though somewhat altered and impaired by the violence of the times, had in great measure weathered the rude shock of the Norman conquest (Blackstone 1893a, 34). "This does not mean that there was any general attempt by the Norman kings to replace English customs by Norman Law. This they expressly disclaimed. [...] Therefore, law and life in England stayed with little change after the Conquest. The Normans thought of themselves as set apart and did not trouble with the laws of the Anglo-Saxons" (Potter 1948, 10).

${ }^{3}$ Blackstone writes: "The ancient collection of unwritten maxims and customs, which is called the common law, however compounded or from whatever fountains derived, had subsisted immemorially in this kingdom; and, though somewhat altered and impaired by the violence of the times, had in great measure weathered the rude shock of the Norman conquest" $(1893,34)$.

4 "Profound legal and economic changes necessarily suppose a certain change in cultural expectations. That cultural change was embodied in Magna Carta. Magna Carta in some sense was the consequence of a multiplicity of problems that made King John vulnerable to baronial rebellion. In a deeper sense, however, Magna Carta resulted from a change in attitude about the proper role of discretion in lordship: about the nature of justice" (Palmer 1985b, 390). 
successfully revolted, forcing John to sign $M C$, acknowledge the rights and privileges of the barons and the church. The extent to which royal powers should be limited remained unsettled and the $M C$ was re-issued several times throughout the $13^{\text {th }}$ century. What was clear was that the Angevin and Plantagenet kings were weaker than William had been, bound by enumerated rights and privileges.

Some legal historians caution against broader, constitutional interpretation of $M C$, noting that it was a specific agreement made between King John and the rebelling nobles (Plucknett 2010, 23; Turner 2003, 1; Palmer 1985a, 13, 17; McKechnie 1914, 3, 50-51). ${ }^{5}$ This pragmatic, historical interpretation, opposes the more romantic notion that it was a renewal of some ancient constitution of liberty, as in Blackstone (1893a; 1893b) and Coke (2003). This romantic myth of $M C$ was not possible before the modern idea of the state emerged during the Renaissance and the Reformation (Plucknett 2010, 142), as was later associated with the Whig political movement, including the United States' Revolution (Turner 2003, 1-7, 196-199), and anytime there are feelings against the Crown in English history, such as Coke (2003). It is this myth that, in many ways taken on a life of its own, that has become a powerful rallying cry for freedom over the last 800 years. $^{6}$ To put it plainly, in every era there is a new interpretation of the $M C$, though one of the unifying threads is that it was a product of the unique, historical circumstances of $13^{\text {th }}$ century England. As such, the myth of the $M C$ and the uniqueness of British legal-historical exceptionalism are mutually reinforcing. ${ }^{7}$ The $M C$ has been previously compared with Polish legal history, but with the Henrician articles, rather than $K E$. At first glance, this may be the more natural comparison, as Malec has done (2016, 140-143), and $K E$ risking novelty for its own sake. However, there are two objections to this, both historical in nature: first, the writing of $M C$ and $K E$ both date to the $13^{\text {th }}$ century, and give insight into a wide variety of secondary issues in Europe at the time, such

5 "Their [the barons'] complaints, as they appear in the imperishable record of Magna Carta, are grounded on technical rules of feudal usage, not upon any broad basis of constitutional principle" (McKechnie 1914, 49).

${ }^{6}$ Champion et al (2015) give a deeper discussion of this "myth".

${ }^{7}$ Thus, the more romantic commentators, such as Blackstone and Coke, who seek to frame the $M C$ as a return to Anglo-Saxon laws and freedom as well as those who interpret the $M C$ as a local political act of the barons' to secure their rights rather than an attempt to build a specific constitutional system, both have a tendency to over-emphasize the uniqueness and specificity of British legal history. The approach outlined in this paper agrees with as well as disagrees with different aspects of both approaches. There are two aspects that naturally follow from the recognition of the $M C$ as a myth: first, that it was intended locally rather than constitutionally, and should be thought of historically, yet, also that its role as a myth or idea has taken on a life of its own, so to speak. Thus, thematically, the approach agrees with the more romantic, "classical" view of the $M C$ as a source of inspiration for freedom throughout legal history, whereas substantively, it agrees with those who argue for a localized understanding. Ironically, this local understanding allows for more general approaches across time and space if its contextualist epistemology is wedded to a praxeological view of human nature. 
as developments in feudalism and within the Catholic Church. Secondly, the Henrician articles were the first constitution of Poland-Lithuania, and to compare it with $M C$ on constitutional grounds is problematic, for reasons outlined above. Thus, while the myth of $M C$ may be more directly comparable with the Henrician articles, the actual writing of the Great Charter in its own time and context is more appropriately compared with $K E$.

The $13^{\text {th }}$ century in Poland has many similar parallels to that of England. First, the local dynasty had been in a period of decline due to infighting and invasion of the Mongols, whose internal weakness invited the Order of Brothers of the German House of Saint Mary in Jerusalem (commonly known as the Teutonic Knights or the Teutonic Order) to launch a crusade. The Knights eventually conquered much of northern Poland and Lithuania along the Baltic coast, establishing or heavily fortifying the cities of Gdańsk (Danzig), Elbląg (Elbing), and Torun (Thorn), which became the wealthiest cities in the region, dominated by foreign, German nobles, adopting their language and culture (Magosci 2018; Hybel 2008, 4-5, 12-14; Unger 2008, xxix, xxxii-xxxiii; Urban 1998; Knoll 1967; Dziewanowski 1963, 444-448).

Legal historians have debated whether $K E$ is German or Polish, as it was written in an old German dialect or in Latin, though in his introduction Matuszewski addresses the issue clearly: its name comes from the city of Elblagg as this was the regional capital and where the courts would have been located, but it clearly contains legal elements not present in German law at the time, such as a specific legal argument for casuistry (Matuszewski 1959, 8, 63-65, 68-70, 103104). Though brutal toward pagans, the Order was relatively flexible in gathering and assimilating local peoples to continue their crusade (Urban 1998, 196, 201, 204-205), even allowing them self-rule according to their own laws and customs. The $K E$ is one such example (Matuszewski 1967, 66-67).

Like that of the Normans, the Teutonic Order's rule was challenged over the centuries. As the text demonstrates below, the Poles retained their pride in their local traditions, with the clergy developing the theory of just war, that stated that the only kind of law that was just was to restore man's natural freedom, given by God. To this end, rebellion against the king, the Pope, and uniting with heathens were justified in wars of liberation. Given that the Lithuanians were still pagan at the time, this drew the fates of the Poles and the Lithuanians ever closer together, eventually uniting to drive back the Order (Owczarska 2014, 158-162). Though $K E$, as it was the Teutonic Order's codification of Polish legal traditions in a form of self-rule, was not constitutional per se, it is evidence of the budding Polish identity, especially its opposition against imperial or German rulers, an identity that was carried throughout the centuries. 


\section{COMPARING THE TEXTS}

These religious and socio-historical similarities are evidenced by what effectively serve as the preambles to the texts themselves. The $K E$ opens with a bold claim ${ }^{8}$ :

[1.1] Dypolenscherectkonnen wellen, den sie wissintlich, dazdy Polen, von ircristenheitangende, habin den rinyschebstule des bobistesundirtenikgewesinundenict dem styl in synem schirm impfing, dorchdazzedestegernircristenwordin.

[1.2] Durch dazorkundegebynzejerlichzcu pflege eynirhande gelt dem vorgenantemstule. Dazheisetsente Petirspfenning.

[2.1] Unde wen irgericht von dem keyser in gywerlt nicht enkumt, alzdutschervurstenunderichter tut, | zoenhabinzedez keine gewoneit, das zeirgerichthegyn | von obirgewalt, alzdutscherichter pflegen zcu tun.

[2.2] Wazabirzegerichtin, adirwaz vor in bekantwirt, adirgeloukint, | daz hat zo getane macht, alzemarkgreven | unde etlicher dutschenvursten, dyir ding nicht enhegin.

[1.1] Tym, którzy chca znać prawo polskie, niech będzie wiadomo, że Polacy od chwili (przyjęcia) przez siebie chrześcijaństwa podlegali rzymskiej stolicy papieża, a nie cesarzowi, gdyż ich rzymska stolica wzięla pod swoja opieke, dzięki czemu tym chętniej stali się chrześcijanami.

[1.2] Na świadectwo tego daja corocznie tytułem czynszu wyżej wymienionej stolicy garść pieniędzy, co się nazywa pieniążkiem świętego Piotra.

[2.1] A ponieważ ich (tj. Polaków) władza sadowa nie wyptywa od cesarza, jak (taż władza) niemieckich książą i sędziów, dlatego nie mają oni zwyczaju gajenia swoich sądów z mocy władzy zwierzchniej, jak to zwykli czynić niemieccy sędziowie.

[2.2] Wszakże co oni osądza albo co przed nimi się przyzna, albo czemu zaprzeczy, to ma taka sama moc, jakby (wychodzito) od margrabiów i niektórych niemieckich książat, którzy swego sąu nie gaja (z mocy władzy zwierzchniej).

[1.1] To those who want to know Polish law, let it be known that the Poles have been subject to the Roman capital of the Pope since the moment of (their adoption) of Christianity, and not to the Emperor, because their Roman capital was under their protection, making them all the more willing to become Christians.

[1.2] In testament, each year they give a handful of money for the above-mentioned capital, which is called the Peter's Pence.

[2.1] And because their judicial authority does not flow from the Emperor, as (the authority of) the German princes and judges, therefore they have no habit of adorning their judgments by virtue of supreme authority, as the German judges usually do.

[2.2] After all, what will they judge or what they will admit to them, or what will be denied, it has the same power as (if it came) from the Margraves and some German princes who do not adorn their own court (by virtue of superior authority).

These are not meek works of conquered people, but those who genuinely saw themselves as equals in the eyes of the Church, which gave the Poles the

${ }^{8}$ The Old German-Prussian and the Polish translation are by Matuszewski (1959). The English translation from Polish is my own. 
right to their own laws. This rejection of equating the authority of the Emperor with the authority of the Church was somewhat unique for its time, and a point of contention between the Poles and Lithuanians against the Teutonic Order, eventually resulting in the defeat and ousting of the Order and the creation of the Polish-Lithuanian Commonwealth. This statement of asserting their right to rule and rejection of imperial rule recalls the first chapter of $M C$ :

In primis concessisse Deo et hac presenti carta nostra confirmasse, pro nobis et heredibus nostris in perpetuum, quod Anglicana ecclesia libera sit, et habeat jura sua integra, et libertates suas illesas; et ita volumus observari; quod apparet ex eo quod libertatem electionum, que maxima et magis necessaria reputatur ecclesie Anglicane, mera et spontanea voluntate, ante discordiam inter nos et barones nostros motam, concessimus et carta nostra confirmavimus, et eam obtinuimus a domino papa Innocencio tercio confirmari; quam et nos observabimus et ab heredibus nostris in perpetuum bona fide volumus observari. 3 Concessimus eciam omnibus liberis hominibus regni nostri, pro nobis et heredibus nostris in perpetuum, omnes libertates subscriptas, habendas et tenendas eis et heredibus suis, de nobis et heredibus nostris.

In the first place we have granted to God, and by this our present charter confirmed for us and our heirs forever that the English church shall be free, and shall have her rights entire, and her liberties inviolate; and we will that it be thus observed; which is apparent from this that the freedom of elections, which is reckoned most important and very essential to the English church, we, of our pure and unconstrained will, did grant, and did by our charter confirm and did obtain the ratification of the same from our lord, Pope Innocent III, before the quarrel arose between us and our barons: and this we will observe, and our will is that it be observed in good faith by our heirs forever. We have also granted to all freemen of our kingdom, for us and our heirs forever, all the underwritten liberties, to be had and held by them and their heirs, of us and our heirs forever. ${ }^{9}$

As such, both $M C$ and $K E$ are pacts of sorts, worked out between the people and the sovereign. While both represent a kind of legal-social solution, $M C$ was made from a position of strength by the barons, and tends to reflect the interests of the barons and the Church, while $K E$ is almost entirely concerned with the situation of the peasants and occasionally the knights. A final point of comparison worth making is similarities in legal procedure. The $M C$ has become famous for its thirty-eighth and thirty-ninth chapters, which respectively outline the importance of witnesses and jury by one's peers.

Nullus ballivus ponat de cetero aliquem ad legem simplici loquela sua, sine testibus fidelibus ad hoc inductis.

No bailiff for the future shall, upon his own unsupported complaint, put anyone to his "law," without credible witnesses brought for this purpose (Chapter 38). ${ }^{10}$

${ }^{9}$ McKechnie (1914, 190-191). The original Latin and English translation of the $M C$ are taken from McKechnie.

${ }^{10}$ McKechnie $(1914,369)$. 
Nullus liber homo capiatur vel imprisonetur, aut disseisiatur, aut utlagetur, aut exuletur, aut aliquo modo destruatur, nec super eum ibimus, nec super eum mittemus, nisi per legale judicium parium suorum vel per legem terrae.

No freeman shall be taken or [and] imprisoned or disseized or exiled or in any way destroyed, nor will we go upon him nor send upon him, except by the lawful judgment of his peers or [and] by the law of the land (Chapter 39). ${ }^{11}$

Surprisingly, the entire fifth chapter of $K E$ goes into extensive detail about how to handle witnesses: how much to pay them, what oaths they are to swear, how to ensure that they are not bribed, how to punish bribed witnesses, etc. Section 5.2. gives the greatest detail:

[5.1] Jeśli odpowiadając na skargę mówi, że jest niewinny, wówczas pyta go sędzia, czy ma świadka.

[5.2] Jeśli twierdzi, że go ma, wówczas [sędzia] nakazuje mu, by go [świadka] wymienił, podał jego imię. Gdy on ich wymienia, wówczas po podaniu imienia każdego świadka z osobna, sędzia pyta skarżącego, czy go przyjmuje; on może odrzec: tak albo nie. Którego zaś on przyjmuje, tego sędzia poleca zapisać. Kiedy wszyscy są zapisani, wówczas sędzia poleca, by ich stawił czternastego dnia.

[5.1] If he responds by saying that he is innocent, then the judge asks him if he has a witness. [5.2] If he claims he has him, then [the judge] orders him to name him [the witness], give [the judge] his name. When he mentions them, then after giving the name of each witness individually, the judge asks the applicant whether he accepts it; he can say: yes or no. Which he accepts, the judge recommends registration. When everyone is registered, the judge recommends that they appear on the fourteenth day.

Though not a right to trial by jury of one's peers per se, the individual before the court has great freedom to choose their own witnesses, presumably persons they know and hence a peer. Thus, both the Polish peasanty and minor nobility under $K E$ as well as the English lords under $M C$ have some degree of legal rights against the arbitrary power of the sovereign, which would not exist in the inquisitorial legal system of an imperial ruler.

\section{CONCLUSION}

The Magna Carta and Ksiega Elblaska were products of similar sociohistorical situations where an invading sovereign power compromised with local inhabitants, producing legal systems that limited the arbitrary power of the king or princes. As both documents serve as (at least partial foundations) for their respective legal orders, this casts doubts onto neat categorization of Polish law as civil law and English law as common law as overly simplistic. s. As noted in the paper, the Henrician articles have already been compared with British

\footnotetext{
${ }^{11}$ McKechnie (1914, 375).
} 
legal history; another interesting practise developed in the Kingdom of Poland and continued through the Polish-Lithuanian Commonwealth was neminem captivabimus, which is similar to the development of habeas corpus. Can the development of the Polish(-Lithuanian) system due to socio-historical situation be demonstrated as was with the $K E$ ? Can further comparisons be made between the Polish situation and that of England? Did the $K E$ and similar early Polish legal documents continue to play a role in the sociological legal imagination as the $M C$ did? Indeed, more comparative, contextualist research is needed emphasizing the emergence, convergence, and differentiation of these legal systems in light of political, social, and historic circumstances.

\section{BIBLIOGRAPHY}

Arnold, Morris S. 1977. "Statutes as Judgments: The Natural Law Theory of Parliamentary Activity in Medieval England”. University of Pennsylvania Law Review 126 (2): 329-343.

Baker, John Hamilton. 1990. An Introduction to English Legal History. $4^{\text {th }}$ edition. Oxford: Butterworths.

Blackstone, Sir William. Edited by George Sharswood. 1893a. Commentaries on the Laws of England in Four Books. Notes Selected from the editions of Archibald, Christian, Coleridge, Chitty, Stewart, Kerr, and others, Barron Field's Analysis, and Additional Notes, and a Life of the Author by George Sharswood. In Two Volumes. Philadelphia: J.B. Lippincott Co. Volume 1: Books I and II. http://files.libertyfund.org/files/2140/Blackstone_1387-01_EBk_ v6.0.pdf Accessed 7.05.2019.

Blackstone, Sir William. Edited by George Sharswood. 1893b. Commentaries on the Laws of England in Four Books. Notes Selected from the editions of Archibald, Christian, Coleridge, Chitty, Stewart, Kerr, and others, Barron Field's Analysis, and Additional Notes, and a Life of the Author by George Sharswood. In Two Volumes. Philadelphia: J.B. Lippincott Co. Volume 2: Books III and IV. http://lf-oll.s3.amazonaws.com/titles/2142/Blackstone_1387-02_ EBk_v6.0.pdf. Accessed 7.05.2019.

Brunner, Heinrich. 1908. "The Sources of English Law”. In Select Essays in Anglo-American Legal History, Vol. 2. Edited by the Committee of the Association of American Law Schools. 12-40. Boston: Little, Brown, and Company.

Champion, Justin. R.H. Helmholz. Nicholas Vincent. David Womersley. 2015. “"Magna Carta After 800 Years: From Liber Homo to Modern Freedom'. A Discussion Held in May, 2015”. Liberty Matters: A Forum for the Discussion of Matters Pertaining to Liberty.

Coke, Sir Edward. 2003. The Selected Writings and Speeches of Sir Edward Coke. Vol. I. Edited by Steve Sheppard. Indianapolis: Liberty Fund.

Czarniawska, Barbara. 2002. "Remembering While Forgetting: The Role of Automorphism in City Management in Warsaw”. Public Administration Review 62 (2): 163-173.

Dziewanowski, M.K. 1963. "Dualism or Trialism? Polish Federal Tradition". The Slavonic and East European Review 41 (97): 442-466.

Fried, Michael S. 1999. "The Evolution of Legal Concepts: The Memetic Perspective". Jurimetrics 39 (3): 291-316.

Gałędek, Michał. Anna Klimaszewska. 2018. “A Controversial Transplant? Debate over the Adaptation of the Napoleonic Code on the Polish Territories in the Early $19^{\text {th }}$ Century". Journal of Civil Law Studies 11: 269-298. 
Glor, Richard E. 2010. "Phylogenetic Insights on Adaptive Radiation". Annual Review of Ecology, Evolution, and Systematics 41: 251-270.

Griffiths, Paul E. 1996. "The Historical Turn in the Study of Adaptation". The British Journal for the Philosophy of Science 47 (4): 511-532.

Hadfield, Gillian K. Barry R. Weingast. 2011. "Endogenous Institutions: Law as a Coordinating Device". University of Southern California Law School, Law and Economics Working Paper Series. Paper 141.

Hostetler, Michael J. 2000. "Intangible Property under the Federal Mail Fraud Statute and the Takings Clause: A Case Study". Duke Law Journal 50 (2): 589-636.

Hybel, Nils. 2008. "Early Commercial Contacts Between England, Prussia, and Poland". In Britain and Poland-Lithuania: Contact and Comparison from the Middle Ages to 1795. Edited by Richard Unger. 3-17. Leiden: Brill.

Karabowicz, Anna. 2014. "Custom and Statue: A Brief History of Their Coexistence in Poland". Krakowskie Studia z Historii Państwa i Prawa 7 (1): 111-131.

Knoll, Paul W. 1967. "The Stabilization of the Polish Western Frontier Under Casimir the Great, 1333-1370". The Polish Review 12 (4): 3-29.

Lobingier, C. Sumner. 1946. "Precedent in Past and Present Legal Systems". Michigan Law Review 44 (6): 955-996.

De Lolme, Jean Louis. 2007. The Constitution of England; Or, an Account of the English Government. Edited and with and introduction by David Lieberman. Indianapolis: Liberty Fund.

Magosci, Paul Robert. 2018. "Poland, Lithuania, and Bohemia-Moravia, $13^{\text {th }}-15^{\text {th }}$ centuries". In Historical Atlas of Central Europe: Third Revised and Expanded Edition. 2-4. University of Toronto Press: Toronto.

Maitland, Frederick William. 1908. "Materials for the History of English Law". In Select Essays in Anglo-American Legal History. Vol. 2. Edited by the Committee of the Association of American Law Schools. 41-62. Boston: Little, Brown, and Company.

Malec, Dorota. 2016. "The Nobility's Privileges and the Formation of Civil Liberties in Old Poland". In Magna Carta: A Central European Perspective of Our Common Heritage of Freedom. Edited by Zbigniew Rau, Przemysław Żurawski vel Grajewski, Marek Tracz-Tryniecki. 127-166. London: Routledge.

Matuszewski, Jacek. 2015. "Dlaczego nie uczono prawa polskiego na akademii? Prawo zwyczajowe w kulturze oralnej i w kulturze pisma”. Krakowskie Studia z Historii Państwa i Prawa 3: $215-228$.

Matuszewski, Józef. 1959. Najstarszy Zwód Prawa Polskiego. Warsaw: Państwowe Wydawnictwo Naukowe.

McKechnie, William Sharp. 1914. Magna Carta: A Commentary on the Great Charter of King John. $2^{\text {nd }}$ Edition. Glasgow: James Maclehose and Sons.

Milsom, S.F.C. 1969. Historical Foundations of the Common Law. London: Butterworth.

Owczarska, Małgorzata. 2014. "Uniwersytet Krakowski w europejskim dyskursie politycznym początku XV w." In Bellum Iustum versus Bellum Sacrum: Uniwersalny spór w refleksji średniowiecznej Konstancja 1414-1418. Edited by Zbigniew Rau, Tomasz Tulejski. 125-163. Toruń: Wydawnictwo Adam Marszałek.

Palmer, Robert C. 1985a. "The Origins of Property in England". Law and History Review 3 (1): $1-50$.

Palmer, Robert C. 1985b. "The Economic and Cultural Impact of the Origins of Property: 11801220". Law and History Review 3 (2): 375-396.

Plucknett, Theodore Frank Thomas. 2010. A Concise History of the Common Law. $5^{\text {th }}$ edition. Indianapolis: Liberty Fund. 
Pollock, Sir Frederick. Frederic William Maitland. 2010. The History of English Law before the Time of Edward I. Reprint of $2^{\text {nd }}$ Edition, with a Select Bibliography and Notes by Professor S.F. Milsom. Indianapolis: Liberty Fund.

Potter, Harold. 1948. An Historical Introduction to English Law and Its Institutions. London: Sweet and Maxwell.

Ruhl, J.B. 1996. "Fitness of Law: Using Complexity Theory to Describe the Evolution of Law and Society and Its Practical Meaning for Democracy". Vanderbilt Law Review 49: 1406-1459.

Saks, Michael J., Samantha L. Neufeld. 2011. "Convergent Evolution in Law and Science: The Structure of Decision-Making Under Uncertainty". Law, Probability, and Risk 10: 133-148.

Saks, Michael J., Samantha L. Neufeld. 2012. "Parallels in Law and Statistics: Decision Making Under Uncertainty". Jurimetrics 52 (2): 117-122.

Turner, Ralph V. 2003. Magna Carta: Through the Ages. Harlow: Pearson Education Limited.

Unger, Richard. Ed. 2008. Britain and Poland-Lithuania: Contact and Comparison from the Middle Ages to 1795. Leiden: Brill.

Urban, William L. 1998. "Victims of the Baltic Crusade". Journal of Baltic Studies 29 (3): 195-212.

\section{J. Patrick Higgins}

\section{WIĘCEJ WSPÓLNEGO (PRAWA) NIŻ ORYGINALNEJ MYŚLI? WSTĘPNE PORÓWNANIE TEORETYCZNE MAGNA CARTA I KSIĘGI ELBLĄSKIEJ}

Streszczenie. Uczeni zajmujący się prawem w epoce średniowiecza na ogół nie porównują polskich i angielskich systemów prawnych, choć w XIII wieku cechowała je zaskakująca liczba podobieństw. Jest to szczególnie wyraźne, jeśli weźmie się pod uwagę zbieżność ewolucji instytucji prawnych będącą odpowiedzią na problemy społeczno-historyczne epoki. Bezpośrednio ilustruje to historyczna i tekstowa analiza Magna Carta i Księgi Elbląskiej, dwóch kluczowych tekstów dla rodzimych systemów prawnych. W artykule omówiono możliwości płynące z tej nowej perspektywy porównawczej, wraz ze wskazaniem kierunków dalszych badań.

Słowa kluczowe: Księga Elbląska; Magna Carta; Porównawcze historia prawa; zbieżna ewolucja prawna. 